\title{
Editorial
}

\section{ALGUNS ASPECTOS DA LEI 6.229 DE 17 JULHO DE 1975, QUE DISPÕE SOBRE A ORGANIZAÇÃO DO SISTEMA NACIONAL DE SAÚDE}

O campo de ação do Ministério da Saúde - atuando com medidas de interesse coletivo - abrange, entre outras atribuições, elaborar planos e normas para conhecer o estado sanitário da população do País e avaliar os recursos disponiveis para a assistência sanitária.

O Ministério da Saúde submeterá, para aprovação, a Política Nacional da Saúde. Esta atribuição o caracteriza como o órgão coordenador dessa Política.

A Lei 6229/75 estabelece, além do campo do Ministério da Saúde, as seguintes atribuições para os demais campos.

1. O Ministério da Previdência e Assistência Social atua com medidas médico-sanitárias individualizadas. $O$ grande executor nacional da assistência à saúde é esse Ministério.

2. O Ministério do Interior atua em saneamento e ainda, radicação de população, como o tem feito nas novas agrovilas amazônicas.

3. ${ }^{\circ}$ O Ministério do Trabalho atua em higiene e segurança do trabalho, prevenção de acidentes, de doenças profis- sionais e do trabalho, em proteção e disciplina corporativa e política salarial das profissões (por exemplo, por meio dos Conselhos Federal e Regional e dos Sindicatos).

4. ${ }^{\circ}$ Os demais Ministérios que atuarem em programas de saúde específicos devem fazer tal planejamento de modo integrado à Política Nacional de Saúde. Exemplo desta atuação específica são as Forças Armadas e Militarizadas.

O Sistema Nacional de Saúde abrange também outra ordem de componentes que são essenciais, a saber, os subsistemas de saúde dos Estados, Distrito Federal e Territórios. Cabe a cada uma dessas Unidades da Federação instituir seu Plano Integrado de Saúde, articulado com o Plano Federal de Proteção e Recuperação da Saúde, e este com o Plano Nacional de Saneamento e, ainda, Planos Setoriais dos Ministérios, no que implicar em interrelacionamento.

Este é o momento oportuno. A ABEn vê com renovadas espectativas as providências institucionais acima descritas Temos ânimo em trazer nossa contribuição para um bom desempenho da Política Nacional de Saúde. (HGD) 